University of Nebraska - Lincoln

DigitalCommons@University of Nebraska - Lincoln

Publications, Agencies and Staff of the U.S.

Department of Commerce

U.S. Department of Commerce

2006

\title{
BLUE WHALE (BALAENOPTERA MUSCULUS) SIGHTINGS AND RECORDINGS SOUTH OF THE ALEUTIAN ISLANDS
}

\author{
Shannon Rankin \\ National Marine Fisheries Service, shannon.rankin@noaa.gov \\ Jay Barlow \\ National Marine Fisheries Service, jay.barlow@noaa.gov \\ Kathleen M. Stafford \\ University of Washington - Seattle Campus
}

Follow this and additional works at: https://digitalcommons.unl.edu/usdeptcommercepub

Part of the Environmental Sciences Commons

Rankin, Shannon; Barlow, Jay; and Stafford, Kathleen M., "BLUE WHALE (BALAENOPTERA MUSCULUS) SIGHTINGS AND RECORDINGS SOUTH OF THE ALEUTIAN ISLANDS" (2006). Publications, Agencies and Staff of the U.S. Department of Commerce. 309.

https://digitalcommons.unl.edu/usdeptcommercepub/309

This Article is brought to you for free and open access by the U.S. Department of Commerce at DigitalCommons@University of Nebraska - Lincoln. It has been accepted for inclusion in Publications, Agencies and Staff of the U.S. Department of Commerce by an authorized administrator of DigitalCommons@University of Nebraska - Lincoln. 
MARINE MAMMAL SCIENCE, 22(3): 708-713 (July 2006)

(C) 2006 the Society for Marine Mammalogy

No claim to original US government works

DOI: $10.1111 / \mathrm{j} .1748-7692.2006 .00054 . \mathrm{x}$

\title{
BLUE WHALE (BALAENOPTERA MUSCULUS) SIGHTINGS AND RECORDINGS SOUTH OF THE ALEUTIAN ISLANDS
}

\author{
SHANNON RANKIN \\ JAY BARLOW \\ Southwest Fisheries Science Center, \\ National Marine Fisheries Service, \\ 8604 La Jolla Shores Drive, La Jolla, California 92037, U.S.A. \\ E-mail: shannon.rankin@noaa.gov \\ KATHLEEN M. STAFFORD \\ Applied Physics Laboratory, \\ University of Washington, \\ 1013 NE 40th Street, Seattle, Washington 98105, U.S.A.
}

Blue whales have been sighted throughout the North Pacific Ocean (Mizroch et al. 1984), and were harvested around the Pacific Rim from Mexico to Japan (Fig. 1). The International Whaling Commission (IWC) currently recognizes only one stock of blue whales in the North Pacific (Donovan 1991); however, there may be up to five (reviewed in Stafford 2003). While past shipboard and aerial surveys in the Aleutian Island chain found no blue whales (Rice and Wolman 1982, Stewart et al. 1987), their contemporary presence in this area has been well documented by acoustic monitoring (Watkins et al. 2000, Stafford et al. 2001). In this note we present the results of a shipboard survey during which blue whales were seen south of the Aleutian Islands and recordings of blue whale vocalizations were obtained.

Blue whale calls vary geographically (Thompson et al. 1996), and these geographic differences may be useful in discriminating different populations of blue whales. Two geographically and spectrographically distinct blue whale call types have been recorded in the North Pacific. The northeastern Pacific blue whale call type is well known and has been recorded from locations in the northeast Pacific, ranging from the equator along the west coast of North America up to the Gulf of Alaska (Stafford 2003). The northwestern Pacific blue whale call type is less well known, but has been recorded from remote hydrophones near Kaneohe, Hawaii, Midway Island, and locations along the Aleutian Islands and northwest Pacific and Gulf of Alaska (Northrup et al. 1971, Thompson and Friedl 1982, Stafford et al. 2001, Stafford 2003). This call type is recorded annually from June through December by seafloor hydrophones just south of the central Aleutian Islands (Stafford et al. 2001).

Prior to this report, the western calls had never been visually linked to a blue whale. The calls have nevertheless been attributed to blue whales based on their similarity to other blue whale calls worldwide: they are long (>10 s), low-frequency (fundamental $<100 \mathrm{~Hz}$ ), frequency-modulated (FM) tonal calls (Thompson et al. 1996, Stafford et al. 2001, Stafford 2003, Rankin et al. 2005). Although fin whale calls are also low 


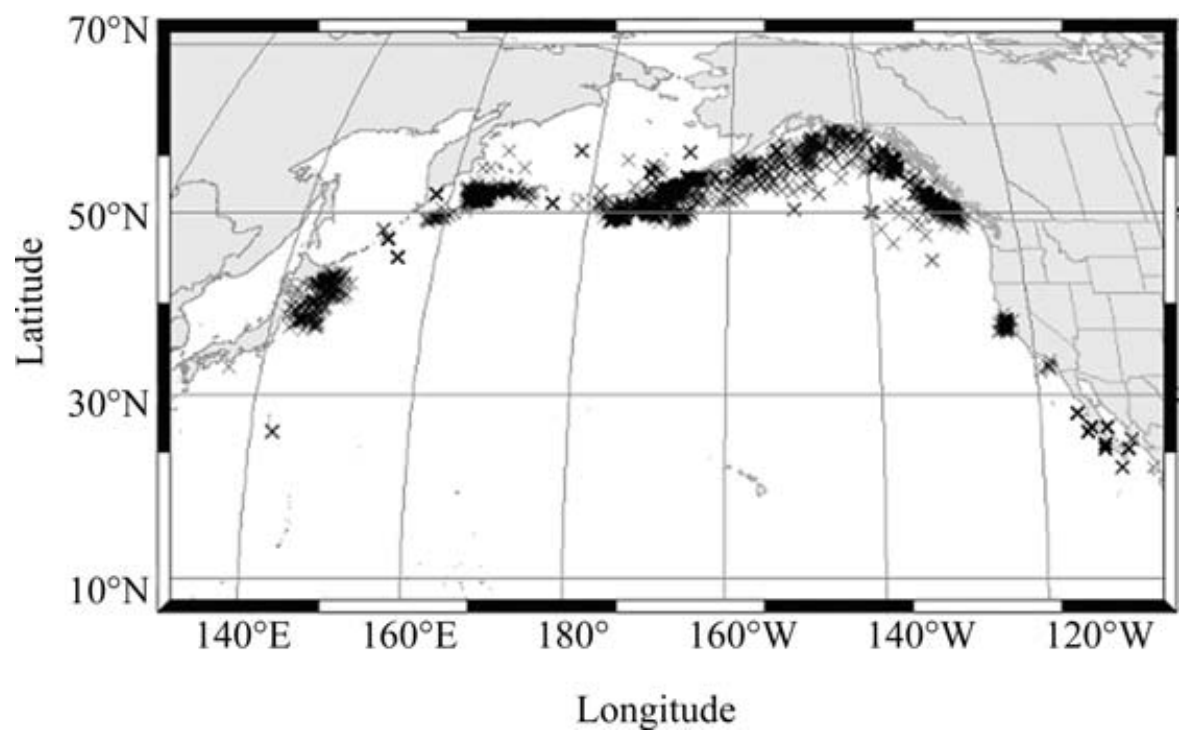

Figure 1. Locations of blue whale kills in the North Pacific Ocean from 1924 to 1965 reported to the International Whaling Commission (IWC Catch database Version 2 December 2002). For further information, contact Cherry Allison, IWC, The Red House, Impington, Cambridge, CB4 4NP, UK).

in frequency, they are generally short $(<1 \mathrm{~s})$, impulsive calls (Thompson and Friedl 1982, Watkins et al. 1987, Thompson et al. 1992). The FM calls of other whales, such as humpbacks or right whales, are both much shorter $(<5 \mathrm{~s})$ and higher in frequency (fundamental $>100 \mathrm{~Hz}$; Thompson et al. 1986, McDonald and Moore 2002).

A 4-mo survey of humpback whales in the North Pacific Ocean provided an opportunity to search for blue whales in offshore waters south of the Aleutian Island Archipelago. The Aleutian portion of the survey was conducted aboard the R/V McArthur II from 27 July through 3 August 2004. Visual line-transect survey methods were conducted following Southwest Fisheries Science Center protocol and included a team of three experienced marine mammal observers rotating between two 25 $\times 150$ binocular positions and a recorder position. When conditions allowed, a rigid-hulled inflatable boat (RHIB) was deployed to approach sighted animals for photo-identification and biopsy.

Recordings were made using Navy surplus AN/SSQ 53-D DIFAR sonobuoys deployed within close proximity to sighted blue whales and from sonobuoys deployed opportunistically south of the Aleutian Island Archipelago. Sonobuoy signals were received on two ICOM IC-R100 radio receivers (Icom America, Bellevue, WA) and recorded on a Sony PCM-R500 digital audio tape recorder (Sony Corporation of America, New York, NY). Signals were monitored aurally via headphones and visually using the real-time spectrographic feature in ISHMAEL (Mellinger 2001). Processing of the DIFAR signals was performed using an automatic function within ISHMAEL, which executes a series of commands for demultiplexing the DIFAR 


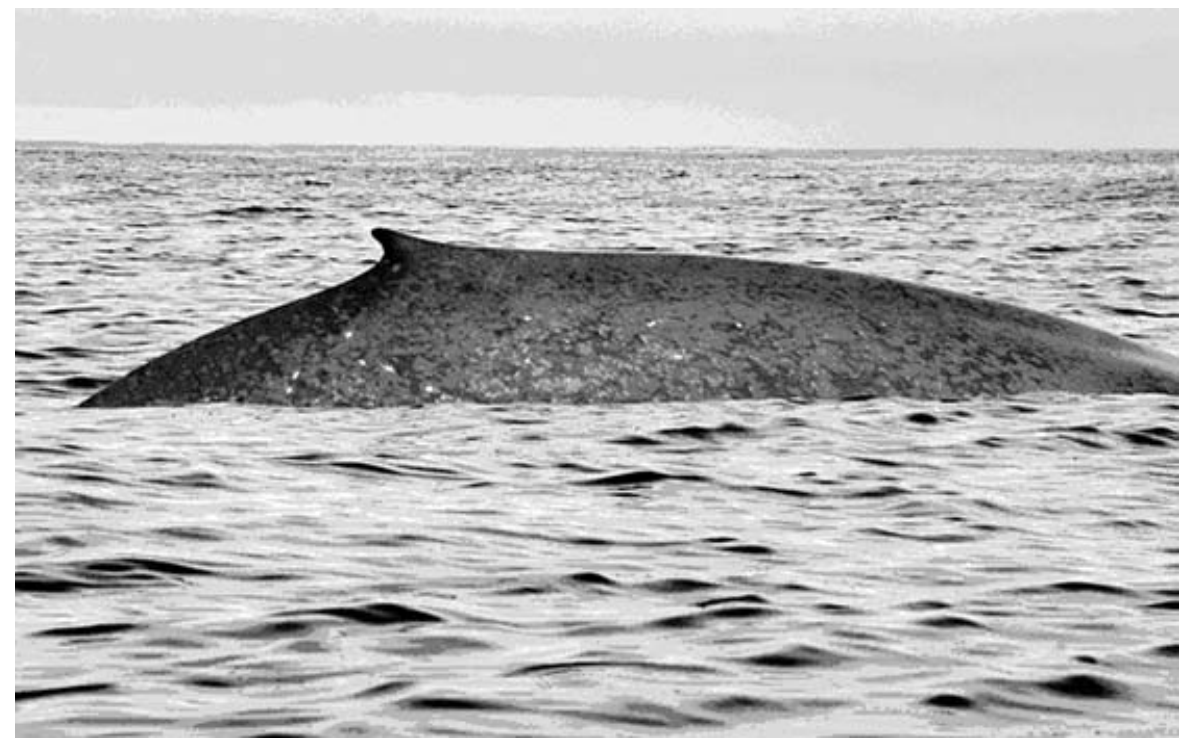

Figure 2. Photograph of the blue whale sighted on 19 August 2004 at $52^{\circ} 3.3^{\prime} \mathrm{N}$, $168^{\circ} 57.0^{\prime} \mathrm{E}$ (photograph by J. C. Salinas, SWFSC/NOAA).

signal (software developed by Greenridge Sciences, Inc.) and determines the bearing to a sound source (software designed by M. McDonald).

On 19 August 2004, a blue whale was sighted at the southwestern most corner of the study area, $257 \mathrm{~km}$ southwest of Attu Island in the Western Aleutian archipelago at $52^{\circ} 3.3^{\prime} \mathrm{N}, 168^{\circ} 57.0^{\prime} \mathrm{E}$ (Fig. 2, 3). The RHIB was deployed, and photographs and a biopsy of the animal were obtained. The whale remained in the general area for at least $3 \mathrm{~h}$, diving regularly with dive intervals of roughly 6-9 min. Three sonobuoys were deployed within $0.5 \mathrm{nmi}$ of the whale, for a total of $2.5 \mathrm{~h}$ of recordings. Several vocalizations attributed to the northwestern stock of blue whales were detected; however, DIFAR bearing angles suggested that the calling animal was $4 \mathrm{nmi}$ south of the sighted blue whale.

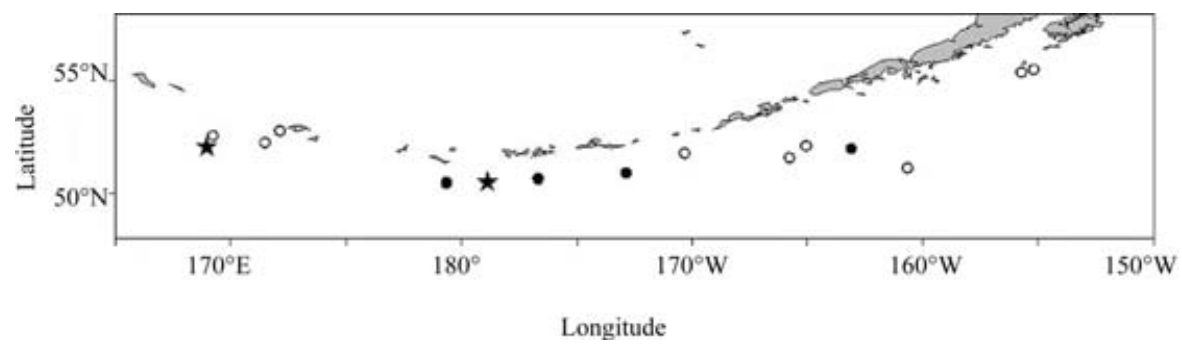

Figure 3. Location of blue whale sightings and opportunistic sonobuoy recordings of blue whales in northwestern and northcentral Pacific Ocean. Confirmed sightings of blue whales are designated with a star. Sonobuoy locations with sounds attributed to northwestern blue whale calls are shown as dark circles, sonobuoy locations with no blue whale sounds are shown as open circles. 


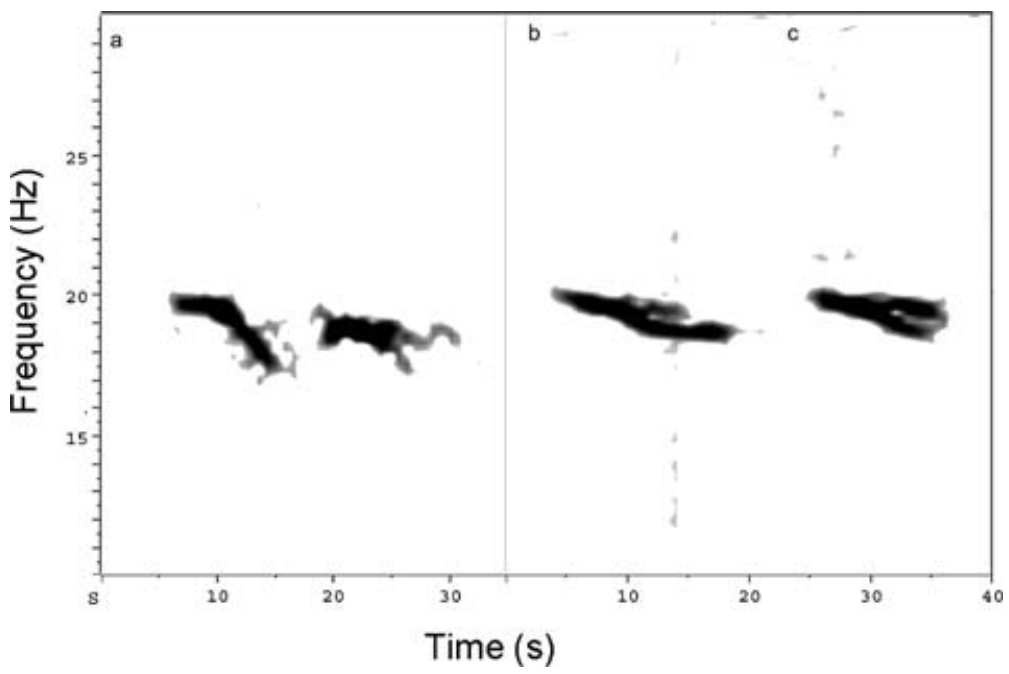

Figure 4. Spectrograms of northwestern Pacific blue whale Type I vocalization recorded in the Gulf of Alaska by Stafford et al. (2001), and Type II and Type V vocalization recorded in the vicinity of the blue whale sighted on 19 August 2004 (2 s FFT, 75\% overlap, Hanning window).

On 23 August 2004, a group of two blue whales was sighted $50 \mathrm{nmi}$ south of Ulak Island in the Central Aleutian Island chain at $50^{\circ} 30.0^{\prime} \mathrm{N}, 178^{\circ} 52.9^{\prime} \mathrm{W}$ (Fig. 3). For the first hour of observation, the animals moved erratically within a $1.5 \mathrm{nmi}$ radius, with dive intervals of roughly 6-10 min. Due to inclement weather, the RHIB was not deployed; photo-identification operations were conducted from the ship, but there were no biopsy attempts. A sonobuoy was deployed within $0.5 \mathrm{nmi}$ of the whales, with over $3 \mathrm{~h}$ of recordings. Vocalizations attributed to the northwestern stock of blue whales were detected during these recordings, but these calls were from distant whales not sighted by the visual observation team.

Two vocalization types were recorded during the 19 August encounter (Fig. 4). The first consisted of a downsweep from 20.0 to $18.4 \mathrm{~Hz}$ over $11.8 \mathrm{~s}( \pm 1.1 \mathrm{~s}, n=6)$ followed by a tone at $18.6 \mathrm{~Hz}$ for $9.8 \mathrm{~s}( \pm 1 \mathrm{~s}, n=6$, Fig. 4). These calls most closely resembled the "type II" western Pacific blue whale calls described by Stafford et al. (2001). The second call type was a downsweep from 20.1 to $18.3 \mathrm{~Hz}$ over $12.9 \mathrm{~s}$ ( \pm 0.7 $\mathrm{s}, n=6$, Fig. 4). This call type is similar to the downsweep found in the "type II" call and the "type III" call described by Stafford $e t$ al. (2001), but sufficiently different to warrant individual recognition. We will call this the "type IV" call, attributed to the northwestern blue whale.

A total of 13 opportunistic sonobuoy deployments were made in the waters of the North Pacific Ocean south of the Aleutian Islands, for a total of more than $27 \mathrm{~h}$ of recordings (Fig. 3). Of these, faint blue whale vocalizations were received during three sonobuoy deployments, and good quality vocalizations were detected during only one of the opportunistic recordings. All vocalizations attributed to blue whales were of the northwestern call types, and no vocalizations attributed to the northeastern blue whale were detected during any of these recordings. 
These are the first well-documented blue whales sighted in the central North Pacific Ocean since whaling operations for blue whales ceased in 1966, and the biopsy samples obtained from the animal on 19 August are the first from a live animal of this population.

The northeastern blue whale stock appears to be increasing in recent years (Calambokidis and Barlow 2004), but little is known about the northwestern blue whale stock. Acoustic surveys detected a greater occurrence of vocalizations in the west than in the east, suggesting that this stock may be larger than sightings indicate. There are insufficient data on the proportion of vocalizing whales or the percentage of the time they are vocalizing. Research on antarctic blue whales suggests that a relatively small proportion of animals may be calling at any one time (Rankin et al. 2005), and the lack of vocalizations from the sighted blue whales in this survey supports this hypothesis. Further efforts should be made to study the vocalizations and associated behavior of this population of blue whales.

\section{ACKNOWLEDGMENTS}

This research could not have been completed without the hard work and dedication of the officers and crew of the R/V McArthur II. Special thanks to the visual observation team: C. Oedekoven, A. Ligon, J. Redfern, S. Hakala, M. Richlen, and B. Taylor. Thanks to T. Chandler for RHIB operations, J.C. Salinas for biopsy operations, E. Zele for assistance with sonobuoy operations, and M. McDonald and C. Greene for their DIFAR software. Funding for this work was provided by the NOAA Southwest Fisheries Science Center and by the U.S. Navy.

\section{LITERATURE CITED}

CALAMBOKIDIS, J., AND J. BARLOW. 2004. Abundance of blue and humpback whales in the eastern North Pacific estimated by capture-recapture and line-transect methods. Marine Mammal Science 20:63-85.

DonOvan, G. P. 1991. A review of IWC stock boundaries. Report of the International Whaling Commission (Special Issue 13):39-68.

MCDONALD, M. A., AND S. E. MOORE. 2002. Calls recorded from North Pacific right whales (Eubalaena japonica) in the eastern Bering Sea. Journal of Cetacean Research and Management 4:261-266.

MELLINGER, D. K. 2001. ISHMAEL 1.0 user's guide. NOAA Technical Memorandum OAR PMEL-120. Available from NOAA/PMEL, 7600 Sand Point Way NE, Seattle, WA 98115-6349.

Mizroch, S. A., D. W. Rice AND J. M. BreiWICK. 1984. The blue whale, Balaenoptera musculus. Marine Fisheries Review 46:15-19.

Northrup, J., W. C. Cummings AND M. F. MORRISON. 1971. Underwater $20 \mathrm{~Hz}$ signals recorded near Midway Island. Journal of the Acoustical Society of America 49:19091910 .

Rankin, S., D. LJungblad, C. Clark AND H. Kato. 2005. Vocalisations of blue whales, Balaenoptera musculus intermedia, recorded during the 2001-2002 and 2002-2003 IWCSOWER circumpolar cruises, Area V, Antarctica. Journal of Cetacean Research and Mangement 7:13-20.

Rice, D. W., AND A. A. Wolman. 1982. Whale census in the Gulf of Alaska June to August 1980. Report of the International Whaling Commission 32:491-497.

STAFFORD, K. M. 2003. Two types of blue whale calls recorded in the Gulf of Alaska. Marine Mammal Science 19:682-693. 
STAFFORD, K. M., S. L. NieUKIRK AND C. G. Fox. 2001. Geographic and seasonal variation of blue whale calls in the North Pacific. Journal of Cetacean Research and Management 3:65-76.

Stewart, B. S., S. A. Karl, P. K. Yochem, S. Leatherwood AND J. L. LaAKe. 1987. Aerial surveys for cetaceans in the former Akutan, Alaska, whaling grounds. Arctic 40:3342.

ThOMPSON, P. O., AND W. A. FRIEDL. 1982. A long-term study of low frequency sounds from several species of whales off Oahu, Hawaii. Cetology 45:1-19.

THOMPSON, P. O., W. C. Cummings AND S. J. HA. 1986. Sounds, source levels, and associated behavior of humpback whales, Southeast Alaska. Journal of the Acoustical Society of America 80:735-740.

THOMPSON, P. O., L. Findley AND O. VIDAL. 1992. 20-Hz pulses and other vocalizations of fin whales, Balaenoptera physalus, in the Gulf of California, Mexico. Journal of the Acoustical Society of America 92:3051-3057.

THOMPSON, P. O., L. T. FINDLEY AND O. VIDAL. 1996. Underwater sounds of blue whales, Balaenoptera musculus, in the Gulf of California, Mexico. Marine Mammal Science 12:288292.

WatKins, W. A., P. TyaCK AND K. E. MoOre. 1987. The 20-Hz signals of finback whales (Balaenoptera physalus). Journal of the Acoustical Society of America 82:1901-1912.

Watkins, W. A., M. A. Daher, G. M. Reppucci, J. E. George, D. L. Martin, N. A. DiMARZIO AND D. P. GANNON. 2000. Seasonality and distribution of whale calls in the North Pacific. Oceanography 13:62-67. 